20. Rabinawitz MB, Needleman HL. Temporal trends in the lead concentrations of umbilical cord blood. Science 1982; $216: 25$

21. Kaul B, Davidow B, Eng YM and Gewirtz MH. Lead, erythrocyte protoporphyrin and ferritin levels in cord blood. Arch Environ Health $1983 ; 38: 396$

22. Woodruff $\mathrm{CW}$. Iron deficiency in infancy and childhood. Pediatr Clin North Am 1977; 24:85
23. National Center for Health Statistics (NCHS). Blood lead levels for persons ages 6 months74 years. United States, 1976-80. Hyattsville, Maryland : US Department of Health and Human Services, 1984

24. Hamilton A. Women in lead industries. Bureau of Labor Statistics Bulletin No. 253, Washington D.C. U.S. Dept. of Labor, 1919. In : Hunt, V. Work and the health of women. Boca Raton : Florida CRC Press Inc., 1979

\title{
MAJOR ROLE FOR VIRUSES IN ACUTE CHILDHOOD ENCEPHALOPATHY
}

The cause of many cases of acute childhood encephalopathy remains unknown. Distinctions within the group are made possible by some consistent clustering of clinical and laboratory features-e.g. in Reye's syndrome or hemorrhagic shock and encephalopathy. An association with viruses is demonstrable in some cases-e.g. influenza $\mathrm{A}$ and varicella zoster are associated with Reye's syndrome. There is evidence of active virus infection in only $20-40 \%$ of the whole group. Meyer et al found evidence of virus infection in $67 \%$, but only by selecting patients with "an acute infectious disease with CNS (central nervous system) manifestations of apparent viral etiology".

The usual diagnostic methods have been virus isolation in the acutc stage of disease and serological tests. However, the presence of interferon in the cerebrospinal fluid (CSF), although only moderately sensitive, is highly specific for viral CNS infection. We report here evidence of a role for viruses in the first comprehensive prospective study of the clinical, virological and immunological features of an unselected series of patients presenting with acute unexplained encephalopathies.

Twenty nine children and 3 adults with acute depression of conscious level or acute onset of focal neurological signs were studied prospectively. Three were found to have a non-infectious cause for their illness. The presence of interferon or specific antibodies in the serum and/or CSF provided evidence of active virus infection in 25 of the remaining 29 patients. There was laboratory evidence that a virus had invaded the central nervous system in 11 patients. Early investigation gave the highest diagnostic yicld. Since several common viruses were identified, it appears that the nature of the illness is due more to the host response than to the nature of the infective agent. 